Role of CA 125 as a tumor marker in ovarian carcinoma. Obstet Gynecol 1986;67:473-7.

11. Brioschi PA, Bischof $P$, Rapin C, De Roten M, Irion O, Krauer F. Longitudinal study of CEA and CA 125 in ovarian cancer. Gynecol Oncol 1985;21:1-6.

12. Altaras MM, Goldberg GL, Levin W, Darge L, Bloch B, Smith JA. The value of cancer antigen 125 as a tumor marker in malignant germ cell tumors of the ovary. Gynecol Oncol 1986;25:150-9.

13. Peters III WA, Bagley CM, Smith MR. CA-125 use as a tumor marker with mixed mesodermal tumors of the female genital tract. Cancer 1986;58:2625-7.

14. Atack DB, Nisker JA, Allen HH, Tustanoff EF, Levin L. CA 125 surveillance and second-look laparotomy in ovarian carcinoma. Am J Obstet Gynecol 1986;154:287-9.

15. Niloff JM, Bast Jr RC, Schaetzl EM, Knapp RC. Predictive value of CA 125 antigen levels in second-look procedures for ovarian cancer. Am J Obstet Gynecol 1985;151:981-6.

16. Shelley MD, Fish RG. Evaluation of an immunoradiometric aseay for the detection of an ovarian tumour marker, CA 125, in serum. Ann Clin Biochem 1986;23:292-6.

17. Package insert, Abbott CA 125-EIA Monoclonal. North Chica- go, Il 60064: Abbott Laboratories, Diagnostics Division, 1987.

18. Galen RS, Gambino SR. Beyond normality. New York: John Wiley and Sons, 1975:13, 33.

19. Westgard JO, Hunt MR. Use and interpretation of common statistical tests in method-comparison studies. Clin Chem 1973;19:49-57.

20. Beck JR, Shultz EK. The use of relative operating characteris tic (ROC) curves in test performance evaluation. Arch Pathol Lab Med 1986;110:13-20.

21. Glick MR, Ryder KW, Jackson SA. Graphical comparisons of interferences in clinical chemistry instrumentation. Clin Chem 1986;32:470-5.

22. Dhokia B, Canney PA, Pectasides D, et al. A new immunoassay using monoclonal antibodies HMGF1 and HMFG2 together with an existing marker CA125 for the serological detection and manage ment of epithelial overian cancer. Br J Cancer 1986;54:891-5.

23. Patton PE, Field CS, Harms RW, Coulam CB. CA-125 levels in endometriosis. Fertil Steril 1986;45:770-3.

24. Mastropaolo W, Fernandez Z, Miller EL. Pronounced increases in the concentration of an ovarian tumor marker CA-125, in serum of a healthy subject during menstruation. Clin Chem 1986;32:21101.

\title{
Influence of Strenuous Exercise on Albumin Excretion
}

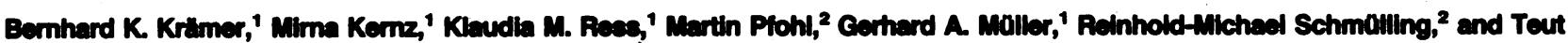 \\ Fivilor'
}

Renal albumin excretion rate was $7.3 \mathrm{mg} / 24 \mathrm{~h}$ (SEM 0.5, range 0.6-21.0) in 66 healthy subjects. This rate increased markedly during and shortly after strenuous exercise on a bicycle ergometer (before: $5.5 \pm 0.6 \mu \mathrm{g} / \mathrm{min}$; during and just after: $16.9 \pm 2.2 \mu \mathrm{g} / \mathrm{min} ; P<0.001 ; n=30$ ). However, albumin excretion/24 $\mathrm{h}$ was not significantly higher during 24 $\mathrm{h}$ with a period of strenuous exercise than during $24 \mathrm{~h}$ without such exercise (10.3 $\pm 0.9 \mathrm{mg} / 24 \mathrm{~h}$ vs $8.5 \pm 0.7 \mathrm{mg} / 24 \mathrm{~h}$ ).

\section{Additional Keyphrases: albuminuria - diabotes - diabotic nephropathy}

End-stage renal disease develops in about $40 \%$ of insulindependent diabetics $(1,2)$, overt proteinuria (>500 $\mathrm{mg}$ of protein or $>300 \mathrm{mg}$ of albumin excreted in $24 \mathrm{~h}$ ) being the hallmark of diabetic nephropathy and a serious prognostic marker (1-3). Pauci("micro")albuminuria is a strong predictor of future overt nephropathy $(4,5)$ in diabetic patients. Early paucialbuminuria can be stopped or even reversed by means of better control of blood glucose or of blood pressure $(3,6,7)$, thus probably slowing or even preventing development of overt diabetic nephropathy. Exact estimation of a slight albuminuria is also of interest for the control of patients with hypertension (8). Our aim in this study was to examine whether 24-h albumin excretion is altered misleadingly by a rather brief period of strenuous exercise during the urine-collection period.

Departments of 1 Internal Medicine III and 2 Internal Medicine IV, University of Tubingen, Otfried-Muller-Str. 10, D-7400 Tubingen, F.R.G.

Received July 11, 1988; accepted September 9, 1988.

\section{Materials and Mothods}

Urinary albumin was measured by enzyme-linked immunosorbent assay as described previously (9). Urine samples were collected in 2-L casein-coated polyethylene containers (9). Albumin excretion was measured in 24-h collections of urine from 66 apparently healthy subjects (eight men and 10 women, ages 20-29 y; 10 men and 10 women, ages $30-39 \mathrm{y}$; eight men and 10 women, ages $40-49 \mathrm{y}$; and five men and five women, ages 50-55 y). In 30 of those subjects (five of each sex in the age ranges 20-29, 30-39, and $40-50$ y) the 24-h collections were made as two 12-h collections (one from 0700 to 1900 hours, the second overnight from 1900 to 0700 hours) to contrast night-time with daytime excretion. With the same 30 subjects, we estimated albumin excretion rate before (period I), during and shortly after (period II), and after (period III) strenuous exercise.. Period I lasted from 0700 to the start of the exercise, period II from the start of the exercise until $1 \mathrm{~h}$ after the end of the exercise, and period III from $1 \mathrm{~h}$ after the exercise until 0700 , hours on the next day.

Results from periods I, II, and III were pooled to provide a 24-h period including exercise, which could then be compared with a 24-h period without exercise in the same subject. The two 24-h urine collections were done within one week, but not on consecutive days. The subjects performed strenuous exercise on a bicycle ergometer (Keiper Dynavit; Meditronic 40/2, 6750 Kaiserslautern, F.R.G.), according to the following protocol: Start with a workload of $30 \mathrm{~W}(\mathrm{~J} / \mathrm{s}$, or $\mathrm{kg} \cdot \mathrm{m}^{2} \cdot \mathrm{s}^{-3}$ ) for $3 \mathrm{~min}$ and increase to $70 \mathrm{~W}$ for $3 \mathrm{~min}$, then further increase the workload by $40 \mathrm{~W}$ every $3 \mathrm{~min}$ until physical exhaustion. Blood pressure was measured with a sphygmomanometer. A statistical evaluation was by means of paired $t$-test; data are reported as mean \pm SEM. 


\section{Results}

For the 66 healthy subjects, the mean 24-h albumin excretion was $7.3 \pm 0.5 \mathrm{mg} / 24 \mathrm{~h}$ (range $0.6-21.0$ ), being 7.8 $\pm 0.8(2.0-21.0) \mathrm{mg} / 24 \mathrm{~h}$ for the women and $6.7 \pm 0.7(0.6-$ 19.5) $\mathrm{mg} / 24 \mathrm{~h}$ for the men. The 12 -h albumin excretion was significantly higher $(P<0.05)$ during day $(4.9 \pm 0.6 \mathrm{mg} / 12$ h) than night (3.6 $\pm 0.3 \mathrm{mg} / 24 \mathrm{~h})$ in 30 of those healthy controls. Albumin excretions per $24 \mathrm{~h}$ by those 30 normal controls during the day of maximal exercise $(10.3 \pm 0.9$ $\mathrm{mg} / 24 \mathrm{~h})$ and during a day without exercise $(8.5 \pm 0.7 \mathrm{mg} / 24$ h) were not significantly different. Albumin excretion rates were significantly higher during period II $(16.9 \pm 2.2$ $\mu \mathrm{g} / \mathrm{min} ; P<0.001)$, during period III $(7.2 \pm 0.8 \mu \mathrm{g} / \mathrm{min}, P$ $<0.05)$, and during period II and III $(7.9 \pm 0.8 \mu \mathrm{g} / \mathrm{min}, P$ $<0.01)$ than during period I $(5.5 \pm 0.6 \mu \mathrm{g} / \mathrm{min})$. Blood pressure rose from $119.0( \pm 1.6) / 77.7( \pm 1.2) \mathrm{mmHg}$ to 171.2 $( \pm 2.7) / 92.8( \pm 1.5) \mathrm{mmHg}$ at the end of maximal exercise, and the heart rate increased from $76.4( \pm 1.4)$ beats/min to $164.4( \pm 2.5)$ beats/min. Maximum workload was $194.7 \pm$ 9.5 W. Albumin excretion per $24 \mathrm{~h}$ exceeded the range of normal values in one patient during the day of maximal exercise $(25.0 \mathrm{mg} / 24 \mathrm{~h})$ compared with a day without exercise $(12.1 \mathrm{mg} / 24 \mathrm{~h})$; all other values remained within the normal range.

\section{Discussion}

An increase in albumin excretion during exercise has been demonstrated both in healthy controls [maximal (1013) or submaximal (14) exercise] and in patients [diabetics, hypertensives; maximal $(12,13)$ or submaximal (13-19) exercise] by various authors, whereas several authors have found no increase in albumin excretion during exercise in healthy controls (submaximal exercise: 12,13,15-19) or in diabetics [maximal (11) or submaximal (12) exercise]. To summarize: increased albumin excretion was demonstrated either in healthy controls or patients during maximal exercise; and during submaximal exercise most authors showed an increase of urinary albumin excretion in diabetics but not in healthy controls. No information is available regarding the influence of a short period of maximal or submaximal exercise on 24-h urinary albumin excretion (10-19).

In agreement with those results, we found that the albumin excretion rate increased markedly during and shortly after maximal exercise in the present study, whereas it was only slightly increased during a later urinecollection period ( $1 \mathrm{~h}$ after the end of exercise until the next morning), and 24-h albumin excretion was not significantly increased during the day that included maximal exercise. However, a possible minor increase in urinary albumin excretion during the day with exercise could have been masked by the known high day-to-day variation (20-25). Indeed, one patient had slightly increased albumin excretion during the day of maximal exercise. We also saw a higher albumin excretion in daytime than overnight, in accordance with the results of other investigators (24-27).

We conclude that urines collected to check for albuminuria need not be discarded because of a short period of exercise during the collection period, although it is preferable to avoid exercise within that period. However, high dayto-day variation may necessitate several estimations, especially if high excretion rates have been detected. Random short-time urine collections may give misleading results because of a prior period of exercise (28). In addition, the effect of exercise may be more marked in patients who are already slightly albuminuric. When overnight urine is used for screening, investigators must keep in mind that albumin excretion is lower during night-time.

\section{References}

1. Andersen AR, Christiansen JS, Andersen JK, Kreiner S, Deckert T. Diabetic nephropathy in Type 1 (insulin-dependent) diabetes: an epidemiological study. Diabetologia 1983;25:496-501.

2. Knowles Jr HC. Magnitude of the renal failure problem in diabetic patients. Kidney Int 1974;4(Suppl):2-7.

3. Mogensen CE. Progression of nephropathy in long-term diabetics with proteinuria and effect of initial anti-hypertensive treatment. Scand J Clin Lab Invest 1976;36:383-8.

4. Mogensen CE, Christensen CK. Predicting diabetic nephropathy in insulin-dependent patients. N Engl J Med 1984;311:89-93.

5. Viberti GC, Hill RD, Jarrett RJ, Argyropoulos A, Mahmud U, Keen $\mathrm{H}$. Microalbuminuria as a predictor of clinical nephropathy in insulin-dependent diabetes mellitus. Lancet 1982;i:1430-2.

6. Christensen CK, Mogensen CE. Effect of antihypertensive treatment on progression of incipient diabetic nephropathy. Hypertension 1985;7(Suppl):109-13.

7. The KROC Collaborative Study Group. Blood glucose control and the evolution of diabetic retinopathy and albuminuria. $A$ preliminary multicenter trial. N Engl J Med 1984;311:365-72.

8. Christensen CK. Rapidly reversible albumin and $\beta_{2}$-microglobulin hyperexcretion in recent severe eseential hypertension. $J$ Hypertension 1983;1:45-51.

9. Krămer BK, Jesse U, Ress KM, Schmülling R-M, Risler T. Enzyme-linked immunosorbent assay for urinary albumin at low concentrations. Clin Chem 1987;33:609-11.

10. Huttunen N-P, Kăăr M-L, Pietilăinen $M$, Vierikko $P$, Reinilă M. Exercise-induced proteinuria in children and adolescents. Scand J Clin Lab Invest 1981;41:583-7.

11. Poortmans J, Dorchy H, Toussaint D. Urinary excretion of total proteins, albumin, and $\beta_{2}$-microglobulin during rest and exercise in diabetic adolescents with and without retinopathy. Diabetes Care 1982;5:617-23.

12. Torffvit O, Castenfors J, Bengtseon U, Agardh C-D. Exercise stimulation in insulin-dependent diabetics, normal increase in albuminuria with abnormal blood pressure response. Scand J Clin Lab Invest 1987;47:253-9.

13. Vittinghus E, Mogensen CE. Graded exercise and protein excretion in diabetic man and the effect of insulin treatment. Kidney Int 1982;21:725-9.

14. Feldt-Rasmuseen B, Baker L, Deckert T. Exercise as a provocative test in early renal disease in type 1 (insulin-dependent) diabetes: albuminuric, systemic and renal haemodynamic responses. Diabetologia 1985;28:389-96.

15. Christensen CK. Abnormal albuminuria and blood pressure rise in incipient diabetic nephropathy induced by exercise. Kidney Int 1984;25:819-23.

16. Dahlquist G, Aperia A, Persson B. Renal function and albuminuria in diabetic children and adolescents: relation to metabolic control and duration. Diabetic Nephropathy 1984;3:117-22.

17. Mogensen CE, Vittinghus $E$. Urinary albumin excretion during exercise in juvenile diabetes. Scand J Clin Lab Invest 1975;35:295300.

18. Pedersen EB, Mogensen CE, Larsen JS. Effects of exercise on urinary excretion of albumin and $\beta_{2}$-microglobulin in young patients with mild eseential hypertension without treatment and during long-term propranolol treatment. Scand $\mathbf{J}$ Clin Invest 1981;41:493-8.

19. Viberti GC, Jarrett RJ, McCartney M, Keen H. Increased glomerular permeability to albumin induced by exercise in diabetic subjects. Diabetologia 1978;14:293-300.

20. Feldt-Rasmussen B, Mathiesen ER. Variability of urinary albumin excretion in incipient diabetic nephropathy. Diabetic Nephropathy 1984;3:101-3.

21. Feldt-Rasmuseen B, Dinesen B, Deckert M. Enzyme immunoaseay: an improved determination of urinary albumin in diabetics 
with incipient nephropathy. Scand J Clin Lab Invest 1985;45:539_ 44.

22. Howey JEA, Browning MCK, Fraser CG. Selecting the optimum specimen for assessing slight albuminuria, and a strategy for clinical investigation: novel uses of data on biological variation. Clin Chem 1987;33:2034-8.

23. Hutchinson AS, O'Reilly DSJ. Normal variations in rate of albumin excretion and albumin to creatinine ratios in nondiabetic children [Letter]. Br Med J 1985;291:1124.

24. Mogensen CE. Urinary albumin excretion in early and longterm juvenile diabetes. Scand J Clin Lab Invest 1971;28:183-93.

25. Rowe DJF, Bagga H, Betts PB. Normal variations in rate of albumin excretion and albumin to creatinine ratios in overnight and daytime urine collections in non-diabetic children. $\mathrm{Br}$ Med J 1985;291:693-4.

26. Davies AG, Postlethwaite RJ, Price DA, Burn JL, Houlton CA, Fielding BA. Urinary albumin excretion in school children. Arch Dis Child 1984;59:625-30.

27. Eshøj O, Feldt-Rasmussen B, Larsen ML, Mogensen EF. The urinary sampling period and examination of urinary albumin excretion. Transplant Proc 1986;18:1652.

28. Wilkin T, Mohamed A, Gatling W, Rowe D. Protein creatinine index and Albustix in assessment of proteinuria [Letter]. Br Med J 1983;287:1883.

\title{
Pyrochemiluminescence ${ }^{\text {Tw }}$ : Real-Time, Cost-Effective Method for Determining Total Urinary Nitrogen in Clinical Nitrogen-Balance Studies
}

\author{
Frank N. Konstantinides, ${ }^{1}$ Kristl A. Bochm, Willam J. Radmer, ${ }^{3}$ Michael C. Storm, ${ }^{2}$ Joseph T. Adderly, ${ }^{4}$ Sally A. Welsdorf, ${ }^{3}$ and Frank \\ B. Corra ${ }^{1,3}$
}

Total urinary nitrogen (TUN) determinations for nitrogenbalance studies were traditionally performed by the Kjeldahl method, but this method is laborious, hazardous, prone to error, and no longer widely available in most clinical laboratories. During the last several decades, urinary urea nitrogen (UUN) determinations have replaced TUN as an index of urinary nitrogen excretion in many clinical laboratories, owing to its ease of determination, decreased cost, and wide availability. However, the validity of using UUN for estimating nitrogen loss has been questioned in many disease states, owing to wide variations in the proportional amount of urea found in TUN. Chemiluminescence has been proposed as an alternative to the Kjeldahl method for TUN. TUN values obtained from 24-h urine collections measured by both micro-Kjeldahl $(x)$ and Pyrochemiluminescence ${ }^{\text {Tw }}(y)$ (Antek Instruments, Inc.) techniques were comparable by linear regression analysis: $n=97 ; r=0.996 ; r^{2}=0.992 ; y=$ $1.048 x-0.606 ; P<0.001$. Automated induction of samples and calculation of results allows up to $\mathbf{4 2}$ samples to be run unattended. This dramatically reduces labor and overall costs for TUN determinations, while providing a more accurate and economical assessment of nitrogen excretion than UUN in a clinical setting.

Additional Keyphrases: economics of laboratory operation · as sessing trauma - chemiluminescence

\footnotetext{
1 Surgical Metabolic Research Facility, St. Paul-Ramsey Medical Center/Ramsey Clinic, St. Paul, MN 55101.

2 Nutrition Research, Kendall McGaw Laboratories, Inc., Irvine, CA 92714.

3 Departments of Pediatrics and Surgery, University of Minnesota Hospitals, Minneapolis, MN 55455.

- Department of Anatomical-Clinical Pathology, St. Paul-Ramsey Medical Center/Ramsey Clinic, St. Paul, MN 55101.

Presented in part at the joint meeting of the American Association for Clinical Chemistry and the Canadian Society of Clinical Chemistry, Chicago, IL, July 13-18, 1986.

Received April 4, 1988; accepted September 2, 1988.
}

The Kjeldahl procedure is the one most widely used for measuring nitrogen in analytical chemistry (1). Determination of total urinary nitrogen (TUN) reflects the extent to which protein catabolism (proteolysis) is occurring after polytrauma or surgical insult or, in some disorders, the extent to which protein malnutrition is occurring. ${ }^{5}$ In many clinical settings, nitrogen balance determinations based on TUN data are an important component of nutrition assesements. TUN determinations by the Kjeldahl method have been criticized as being costly, hazardous, and time consuming. Today, the current micro-Kjeldahl method is safer than the older technology and, although it is slow and expensive, it is still used in many clinical laboratories for TUN determinations.

Urinary urea nitrogen (UUN), because of its lower cost, assay rapidity, and availability, has been proposed as an alternative index of nitrogen excretion for calculating nitrogen balance (2-4). However, the validity of using UUN for estimating nitrogen loss in many disease states (i.e., renal failure and liver disease) has been questioned (5).

A practical instrumental method for measuring the nitrogen content of substances by chemiluminescence was first used in the petrochemical industry to determine the nitrogen content of petroleum products (6). Shortly thereafter, Ward et al. (7), using a modified chemiluminescence analyz$e r$, were able to adapt the concepts of chemiluminescence to measure nitrogen in biological fluids. Other studies $(8,9)$, involving 24-h human urine specimens, have shown ai excellent correlation between classic Kjeldahl analysis and chemiluminescence.

Here we compare the time- and cost-effectiveness of TUN analysis by chemiluminescence with a Model 703C Pyrochemiluminescent ${ }^{\text {Tu }}$ nitrogen system (Antek Instruments, Inc., Houston, TX 77076) with that by traditional Kjeldahl techniques. We also expand our findings for comparison studies between the Pyrochemiluminescence and microKjeldahl technique previously reported (9).

\footnotetext{
6 Nonstandard abbreviations: TUN, total urinary nitrogen; UUN, urinary urea nitrogen; and PCL, Pyrochemiluminescent.
} 